\title{
Nutritional status of cotton plants under fertigation with reuse water and phosphate fertilization
}

\author{
Francisco Gonçalo Filho ${ }^{1}$, Miguel Ferreira Neto ${ }^{1}$, Nildo da S. Dias ${ }^{1}$, José F. de Medeiros ${ }^{1}$, \\ Cleyton dos S. Fernandes ${ }^{1} \&$ Francisco V. da S. Sá ${ }^{1}$
} ${ }^{1}$ Universidade Federal Rural do Semi-Árido/Centro de Ciências Agrárias. Mossoró, RN, Brasil. E-mail: goncalofilho.rn@gmail.com (Corresponding
author) - ORCID: 0000-0001-9335-6863; miguel@ufersa.edu.br - ORCID: 0000-0002-5128-8230; nildo@ufersa.edu.br - ORCID: 0000-0002-1276-5444;
jfmedeir@ufersa.edu.br - ORCID: 0000-0003-1202-8783; cleyton1959@hotmail.com - ORCID: 0000-0002-9465-2637; vanies_agronomia@hotmail.com
- ORCID: 0000-0001-6585-8161

\begin{abstract}
Water reuse is an important practice in water resource management especially in arid and semiarid areas. The objective was to evaluate the mineral composition and boll weight of upland cotton (cultivar BRS 335) plants under fertigation with domestic sewage effluent and phosphate fertilization. An experiment was carried out using randomized block design in a $3 \times 2$ factorial scheme with six repetitions. Cotton plants were fertigated with three fertigation solutions containing domestic sewage effluent (RW) and supply water (SW) in the proportions of $100 \% \mathrm{SW}-\mathrm{T}_{1}, 50 \% \mathrm{SW}+50 \% \mathrm{RW}-\mathrm{T}_{2}$ and $100 \% \mathrm{RW}-\mathrm{T}_{3}$, and two phosphate fertilizer managements (with and without phosphate fertilization at pre-planting). Macronutrient and micronutrient concentrations in the shoots and boll weight were measured and evaluated. Fertigation utilizing reuse water is able to supply both water and part of the nutritional demand of cotton plants. Calcium, copper, iron and zinc concentrations in cotton leaves were below the optimum range for the crop. Reuse water did not meet the total requirements of $\mathrm{Ca}, \mathrm{Cu}, \mathrm{Fe}$ and $\mathrm{Zn}$ of cotton, so complementary mineral supplementation with these nutrients is recommended for the crop to obtain high yield.
\end{abstract}

Key words: Gossipyum hirsutum, water reuse, semi-arid region, foliar diagnosis

\section{Estado nutricional do algodoeiro fertigado com água de reuso e adubação fosfatada}

\begin{abstract}
RESUMO: O reuso de água é uma prática importante no gerenciamento dos recursos hídricos, especialmente nas zonas áridas e semiáridas. Com isso, objetivou-se avaliar o estado nutricional e a massa do capulho do algodoeiro herbáceo (cultivar BRS 335) quando fertigado com efluente de esgoto doméstico e adubação fosfatada. Um experimento foi conduzido em delineamento de blocos ao acaso, em esquema fatorial $3 \times 2$, com seis repetições. As plantas de algodão foram fertigadas com três soluções contendo efluente de esgoto doméstico (AR) e água de abastecimento (AA) nas proporções de $100 \%$ de $\mathrm{AA}-\mathrm{T}_{1}, 50 \% \mathrm{AA}+50 \% \mathrm{AR}-\mathrm{T}_{2} \mathrm{e}$ $100 \% \mathrm{AR}-\mathrm{T}_{3}$ e, dois manejos da adubação fosfatada (com adubação e sem adubação fosfatada em pré-plantio). Foram avaliados os teores de macronutrientes e micronutrientes nas folhas e a massa de capulho. A fertigação com água de reuso é viável para suprir a demanda hídrica e parte da demanda nutricional do algodoeiro. A água de reuso não atendeu aos requisitos totais de $\mathrm{Ca}, \mathrm{Cu}, \mathrm{Fe}$ e $\mathrm{Zn}$ do algodão, portanto, recomenda-se a suplementação mineral complementar com esses nutrientes para que a cultura obtenha alto rendimento.
\end{abstract}

Palavras-chave: Gossipyum hirsutum, reuso de água, região semiárida, diagnose foliar 


\section{INTRODUCTION}

Brazil is the world's fifth largest producer of cotton (Gossipyum hirsutum L. r. latifolium Hutch), ranked after India, China, the United States and Pakistan, and the fourth largest exporter, ranked after the United States, Australia and India (USDA, 2018). However, for cotton yield to be satisfactory in the Brazilian semi-arid region, it is necessary to use to either full or "salvation" irrigation (Lima et al., 2018).

In the world, the problem of water scarcity and the change in water quality due to contamination of water bodies have intensified the use of wastewater treatment techniques (Mekki et al., 2014; Cary et al., 2015). As agriculture is an economic activity responsible for about $70 \%$ of the consumptive use of water resources (Rost et al., 2008; Bonsch et al., 2015), domestic wastewater has great potential for use in agriculture, mainly in semi-arid regions, such as the Brazilian Northeast (Ribeiro et al. 2012; Barbosa et al., 2015). This use would partially release good-quality water sources for human supply and other priority uses in these regions (Abdoulkader et al., 2015; Batista et al., 2017).

Reuse waters, besides serving as a source of water, also have nutritional potential for crops of economic interest. Silva et al. (2013) verified increments in production of up to $169.36 \%$ in cotton plants irrigated with reuse water, compared to those irrigated with public-supply water.

Regarding the demand for phosphorus, compared to other annual crops, cotton requires large amounts of the nutrient, so special attention is needed to the phosphate fertilization of the crop (Aquino et al., 2012).

In view of the above, the objective was to evaluate the nutritional status and boll weight of upland cotton under fertigation with reuse water and phosphate fertilization.

\section{Material ANd Methods}

The experiment was conducted for two cultivation cycles, in the years of 2016 and 2017, in the Milagres Settlement Project, in the municipality of Apodi, located in the mid-west of the Rio Grande do Norte state, at the geographical coordinates of $5^{\circ} 35^{\prime} 18.82^{\prime \prime} \mathrm{S}$ latitude and $37^{\circ} 54^{\prime} 8.48^{\prime}$ ' W longitude, at an altitude of $109 \mathrm{~m}$, and situated in the Apodi Plateau geoenvironment. According to Köppen's classification, the climate of the region is BSw'h', characterized as warm and semi-arid with an average annual temperature of $28.5^{\circ} \mathrm{C}$, with rainy season delaying to autumn (Diniz \& Pereira, 2015).

The experiment was installed in a randomized block design, in a $3 \times 2$ factorial scheme, with three percentages of reuse water (RW) diluted in supply water (SW) applied via fertigation $\left(100 \% \mathrm{SW}-\mathrm{T}_{1}, 50 \% \mathrm{SW}+50 \% \mathrm{RW}-\mathrm{T}_{2}\right.$ and $\left.100 \% \mathrm{RW}-\mathrm{T}_{3}\right)$ and two conditions of phosphate fertilization management (with fertilization and without phosphate fertilization at pre-planting), with six repetitions, totaling 36 experimental units, which together occupy an area of $979.2 \mathrm{~m}^{2}$. Each experimental unit consisted of four rows, at double spacing $(1.10 \times 0.5 \times 0.1 \mathrm{~m})$ with $8.5 \mathrm{~m}$ in length, totaling an area of $27.2 \mathrm{~m}^{2}(3.2 \times 8.5 \mathrm{~m})$, and the usable area was considered as the product of the two central rows with $7.0 \mathrm{~m}$ in length, disregarding $0.75 \mathrm{~m}$ on each end.

The reuse water used in the experiment came from domestic sewage. Its treatment was done in a decanter-digester system coupled with submerged anaerobic filters with upward and downward flow (PROSAB,1999).

The experimental area has flat relief with dominant slope of less than $2 \%$ and the soils that cover it are Inceptisols. Tillage of the area was performed by plowing and harrowing, followed by furrowing. Chemical and physical characterizations of the soil (Table 1) were performed in the Laboratory of Soils, Water and Plants of the Universidade Federal Rural do SemiÁrido - UFERSA, following the methodology of Silva (2009). These data were then used to stipulate phosphate fertilization according to Ribeiro (1999) to obtain high crop yield. The fertilizer was added to the soil and incorporated in the first $0.05 \mathrm{~m}$ depth.

To irrigate the experimental area, water from the primary treatment system and water from the tubular well (150 $\mathrm{m}$ deep) that supplies the community were stored in two distinct tanks

Table 1. Chemical and physical characteristics of the soil of the experimental area

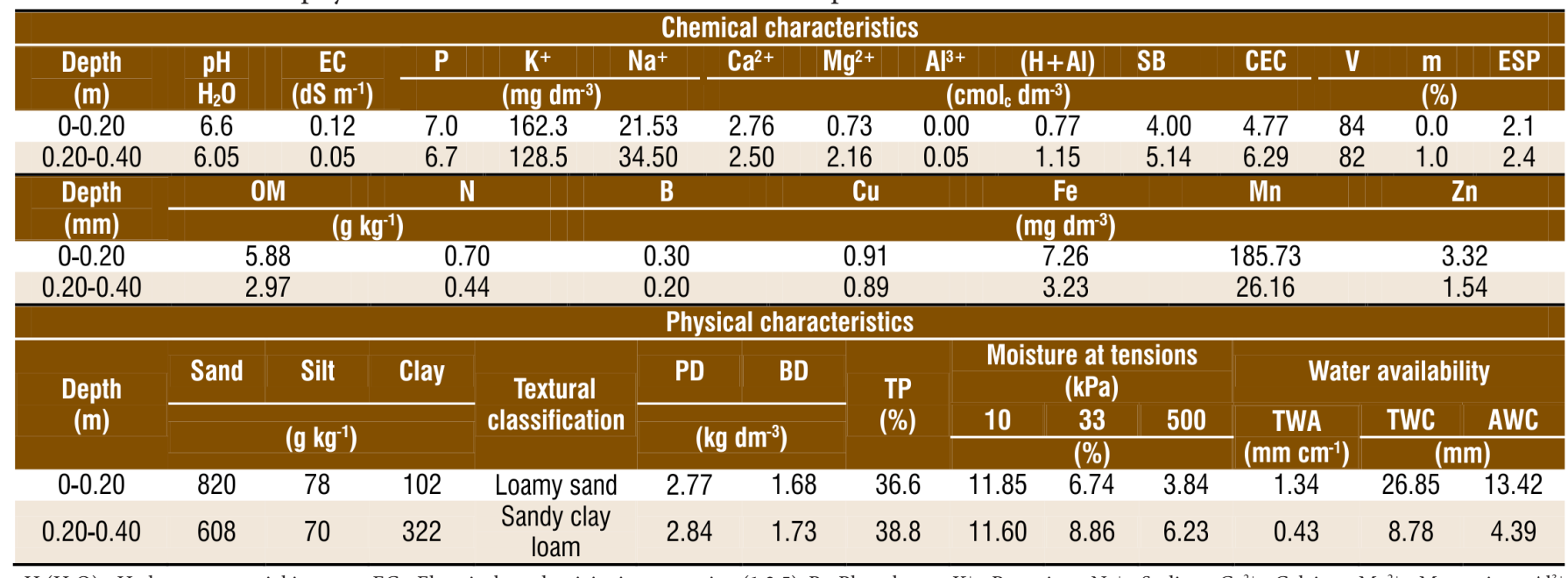

$\mathrm{pH}\left(\mathrm{H}_{2} \mathrm{O}\right)$ - Hydrogen potential in water; EC - Electrical conductivity in suspension (1:2.5); P - Phosphorus; $\mathrm{K}^{+}$- Potassium; $\mathrm{Na}^{+}$- Sodium; $\mathrm{Ca}^{2+}$ - Calcium; $\mathrm{Mg}^{2+}$ - $\mathrm{Magnesium}^{2} \mathrm{Al}^{3+}$ - Aluminum; $\mathrm{H}+\mathrm{Al}$ - Potential acidity; SB - Sum of bases; CEC - Cation exchange capacity; V - Base saturation; $\mathrm{m}$ - Aluminum saturation; ESP - Exchangeable sodium percentage; OM - Organic matter; N - Nitrogen; B - Boron; Cu - Copper; Fe - Iron; Mn - Manganese; Zn - Zinc; PD - Particle density; BD - Bulk density; TP - Total porosity; TWA - Total water availability; TWC - Total water storage capacity; AWC - Actual water storage capacity 
and pressurized by two independent 1.5 -hp electric pump sets. In the localized irrigation system, the different combinations of wastewater percentages were pressurized working always at the same operating pressure of 3 m.w.c.

An irrigation system called "modified bubbler" was used. This system was developed to be resistant to clogging, reduce energy consumption and operate at low pressures (Hao et al., 2017). The system was installed using 3-mm-internal-diameter microtube emitters to avoid clogging by the suspended particles present in the reuse water, so that no sophisticated filtration systems were needed.

The irrigation system was composed of main line and submain line of PVC pipes with diameters of 32 and $50 \mathrm{~mm}$ and polyethylene lateral lines with diameter of $16 \mathrm{~mm}$ in, spaced $3.2 \mathrm{~m}$ apart. In these lines, microtube emitters were connected to feed the 2.0-m-long irrigation furrows, which in sequence, one followed by the other, irrigated the two rows of cotton that were on its margins.

Initially, irrigation was performed with public-supply water in all treatments in order to leave them close to field capacity and, after that, the cultivar BRS 335 was sown by placing 10 seeds per linear meter at a standard depth of 3 $\mathrm{cm}$ from the soil surface and alternated on the sides of the irrigation furrow, in double rows $(1.10 \times 0.5 \times 0.1 \mathrm{~m})$, totaling a population of 125,000 plants ha ${ }^{-1}$. At 10 days after sowing, a period in which germination stabilized, the treatments began to be applied.

Subsequent irrigations were performed based on crop evapotranspiration (ETc), determined as a function of reference evapotranspiration (ETo) calculated by the Penman-Monteith equation parameterized by FAO (Allen et al., 2006). The data were obtained at the climatological station of the Instituto Nacional de Meteorologia - INMET (Apodi, $\mathrm{RN}$ ) and the crop coefficient was determined according to the FAO 56 manual (Allen et al., 2006) (Eq. 1), with an irrigation interval of 2 days. At the end of each day, the climatic data necessary to feed the irrigation worksheet were collected and used to determine the irrigation depth of the next day. When cotton plants had $60 \%$ of the bolls open, the irrigations were suspended.

$$
\mathrm{ETc}=\mathrm{ETo} \mathrm{Kc}
$$

where:

$$
\begin{aligned}
& \text { ETc - crop evapotranspiration; and, } \\
& \text { Kc - crop coefficient. }
\end{aligned}
$$

To calculate the irrigation depth, for a 2-day irrigation interval, the following expression was used:

$$
L=\frac{(\mathrm{ETc} 2)}{\mathrm{f}}
$$

where:

L - irrigation depth, in $\mathrm{mm}$;

ETc - average crop evapotranspiration, in $\mathrm{mm}$; and,

$\mathrm{f}$ - application efficiency (considered equal to 0.85, value of the uniformity distribution coefficient - UDC).
The experiment was installed on October 7, 2016 and on August 11, 2017, for the first and second cycles, respectively. In both cycles: the planting density was $12-13$ plants $\mathrm{m}^{-2}$; fertilization was performed at pre-planting with $100 \mathrm{~kg} \mathrm{ha}^{-1}$ of triple superphosphate, according to treatment. Irrigations with reuse water started at 10 days after planting (DAP) and the last irrigation was performed at 97 and 103 DAP, with depths of 709.7 and $759.1 \mathrm{~mm}$ for cycles 1 and 2, respectively. The duration of the cycles was 113 and 120 DAP, respectively, and during these periods there were no rainfall events.

Weed control was performed mechanically with a hoe, twice, at 15 and at 25 days after germination (DAG). From this point on, additional weeding was not necessary because the shading caused by cotton plants inhibits the emergence of spontaneous plants. Pest sampling was performed weekly and, when populations reached the control level [Bemisia tabaci (Gennadius); Liriomyza trifolii (Burgess)], the following active ingredients were applied using a backpack sprayer (20 L): EVIDENCE $700 \mathrm{WG}^{\oplus}$ (Imidacloprid - $700 \mathrm{~g} \mathrm{ha}^{-1}$ ) at 27 DAP; Abamex BR $18^{\circledast}$ (Abamectin - $\left.18 \mathrm{~g} \mathrm{~L}^{-1}\right)+$ CONNECT $^{\circledast}$ (Beta-cyfluthrin - $12.5 \mathrm{~g} \mathrm{~L}^{-1}$; Imidacloprid - $\left.100 \mathrm{~g} \mathrm{~L}^{-1}\right)+$ Assist $^{\oplus}$ (Mineral oil - $756 \mathrm{~g} \mathrm{~L}^{-1}$ ) at 39 and 82 DAP; Oberon ${ }^{\odot}$ (Spiromesifen $240 \mathrm{~g} \mathrm{~L}^{-1}$ ) at $54 \mathrm{DAP}$; Tiger $100 \mathrm{EC}^{\circledast}$ (Pyriproxyfen - $100 \mathrm{~g} \mathrm{~L}^{-1}$ ) + MOSPILAN WG (Acetamiprid - $200 \mathrm{~g} \mathrm{ha}^{-1}$ ) at 68 DAP, following the manufacturer's recommendation.

In order to monitor the waters used in the experiment, their physical-chemical and biological characteristics were evaluated (Table 2).

For foliar diagnosis, 30 leaves of each experimental unit

\begin{tabular}{|c|c|c|c|c|}
\hline Characteristics & RW $^{1}$ & SD & SW & SD \\
\hline $\mathrm{pH}\left(\mathrm{H}_{2} \mathrm{O}\right)$ & 7.40 & \pm 0.43 & 6.84 & \pm 0.17 \\
\hline $\mathrm{EC}\left(\mathrm{dS} \mathrm{m}^{-1}\right)$ & 1.09 & \pm 0.15 & 0.09 & \pm 0.01 \\
\hline $\mathrm{K}^{+}\left(\mathrm{mg} \mathrm{L}^{-1}\right)$ & 27.37 & \pm 3.91 & 9.38 & \pm 2.74 \\
\hline $\mathrm{Na}^{+}\left(\mathrm{mg} \mathrm{L}^{-1}\right)$ & 74.95 & \pm 12.42 & 3.91 & \pm 0.23 \\
\hline $\mathrm{Ca}^{2}+\left(\mathrm{mg} \mathrm{L}^{-1}\right)$ & 18.44 & \pm 1.80 & 11.14 & \pm 7.29 \\
\hline $\mathrm{Mg}^{2+}\left(\mathrm{mg} \mathrm{L}^{-1}\right)$ & 23.33 & \pm 13.49 & 8.14 & \pm 4.37 \\
\hline $\mathrm{Cl}^{-}\left(\mathrm{mg} \mathrm{L}^{-1}\right)$ & 125.85 & \pm 39.35 & 31.55 & \pm 2.13 \\
\hline $\mathrm{CO}_{3}^{2}\left(\mathrm{mg} \mathrm{L}^{-1}\right)$ & 0 & 0 & 0 & 0 \\
\hline $\mathrm{HCO}_{3}^{-}\left(\mathrm{mg} \mathrm{L}^{-1}\right)$ & 408.70 & \pm 31.11 & 29.28 & \pm 1.83 \\
\hline $\operatorname{SAR}\left(\mathrm{mmol} \mathrm{L}^{-1}\right)^{0.5}$ & 2.80 & \pm 0.48 & 0.21 & \pm 0.10 \\
\hline $\mathrm{P}^{+}\left(\mathrm{mg} \mathrm{L}^{-1}\right)$ & 7.82 & \pm 0.95 & 0.57 & \pm 0.12 \\
\hline $\mathrm{N}-\mathrm{NH}_{4}\left(\mathrm{mg} \mathrm{L}^{-1}\right)$ & 29.91 & \pm 9.29 & 0.56 & \pm 0.98 \\
\hline $\mathrm{N}-\mathrm{NO}_{3}\left(\mathrm{mg} \mathrm{L}^{-1}\right)$ & 14.58 & \pm 18.73 & 0.02 & \pm 0.03 \\
\hline $\mathrm{SS}\left(\mathrm{mg} \mathrm{L}^{-1}\right)$ & 33.00 & \pm 11.00 & 0 & 0 \\
\hline $\mathrm{SD}\left(\mathrm{mg} \mathrm{L}^{-1}\right)$ & 389.00 & \pm 39.00 & 53.00 & \pm 3.00 \\
\hline OGC $\left(\mathrm{mg} \mathrm{L}^{-1}\right)$ & 18.1 & \pm 3.32 & - & - \\
\hline BOD $\left(\mathrm{mg} \mathrm{L}^{-1}\right)$ & 18.75 & \pm 10.90 & - & - \\
\hline $\operatorname{COD}\left(\mathrm{mg} \mathrm{L}^{-1}\right)$ & 94.00 & \pm 10.80 & - & - \\
\hline TC (MPN $100 \mathrm{~mL}^{-1}$ ) & 1100.00 & \pm 169.71 & 0 & \pm 0 \\
\hline TTC (MPN $100 \mathrm{~mL}^{-1}$ ) & 290.00 & \pm 44.74 & 0 & \pm 0 \\
\hline $\mathrm{Cu}\left(\mathrm{mg} \mathrm{L}^{-1}\right)$ & 0.08 & \pm 0.005 & 0.02 & \pm 0.01 \\
\hline $\operatorname{Mn}\left(\mathrm{mg} \mathrm{L}^{-1}\right)$ & 0.08 & \pm 0.009 & 0.06 & \pm 0.01 \\
\hline $\mathrm{Fe}\left(\mathrm{mg} \mathrm{L}^{-1}\right)$ & 0.24 & \pm 0.018 & 0.23 & \pm 0.03 \\
\hline $\mathrm{Zn}\left(\mathrm{mg} \mathrm{L}^{-1}\right)$ & 0.05 & \pm 0.041 & 0.15 & \pm 0.04 \\
\hline $\mathrm{Cr}\left(\mathrm{mg} \mathrm{L}^{-1}\right)$ & 0 & 0 & 0 & 0 \\
\hline $\mathrm{Ni}\left(\mathrm{mg} \mathrm{L}^{-1}\right)$ & 0 & 0 & 0 & 0 \\
\hline $\mathrm{Cd}\left(\mathrm{mg} \mathrm{L}^{-1}\right)$ & 0 & 0 & 0 & 0 \\
\hline $\mathrm{Pb}\left(\mathrm{mg} \mathrm{L}^{-1}\right)$ & 0 & 0 & 0 & 0 \\
\hline
\end{tabular}
were collected, the fifth fully expanded leaf from the tip of

Table 2. Physicochemical and biological characteristics of reuse water (RW) and supply water (SW), used in the experiment

${ }^{1}$ Average values ; SD - Standard deviation; SS - Suspended solids; OGC - oil and grease content; BOD - Biochemical oxygen demand; COD - Chemical oxygen demand; TC - Total coliforms; TTC - Thermotolerant coliforms 
the main stem, in the period of full flowering, according to the methodology proposed by Malavolta et al. (1997). After collection, the leaves were placed in labeled paper bags, dried in a forced circulation oven at $65{ }^{\circ} \mathrm{C}$ until constant weight, crushed in a steel Wiley-type mill, with subsequent storage in labeled plastic bags, and then sent for analysis.

In the laboratory, the material was subjected to wet digestion $\left(\mathrm{H}_{2} \mathrm{SO}_{4} 98 \%+\mathrm{H}_{2} \mathrm{O}_{2} 98 \%\right.$, both of analytical grade) in an open system, to determine the total leaf concentrations of nitrogen $(\mathrm{N})$ by the Kjeldahl method, and to dry digestion to obtain the extract used to read the total leaf concentrations of phosphorus $(\mathrm{P})$, potassium $(\mathrm{K})$, calcium $(\mathrm{Ca})$, magnesium $(\mathrm{Mg})$, boron $(\mathrm{B})$, copper $(\mathrm{Cu})$, iron $(\mathrm{Fe})$, manganese $(\mathrm{Mn})$ and zinc (Zn) according to the procedures described in Silva (2009).

Leaf analysis was interpreted using the method of concentration ranges in leaf dry matter and a subsequent individual comparison of the levels of each nutrient with parameters considered adequate for cotton, described by Malavolta et al. (1997).

To evaluate boll weight, in each crop cycle 20 bolls were harvested from the middle third of the plants in each experimental unit. These bolls were identified and then sent to the Laboratório de Análise de Fibra e Fios of the Centro Nacional de Pesquisa do Algodão (CNPA) - Embrapa Algodão, to determine boll weight, which was obtained by weighing.

The data were subjected to analysis of variance by F test at $\mathrm{p} \leq 0.05$. When significant, the means were compared by Tukey test at $\mathrm{p} \leq 0.05$. All analyses were performed using statistical analysis software SISVAR (Ferreira, 2014).

\section{Results AND Discussion}

Fertigation with reuse water exerted significant influence ( $\mathrm{p} \leq 0.01$ ) on upland cotton boll weight in both cultivation cycles (Table 3 ). Phosphate fertilization management and the interaction between factors were not significant for cotton boll weight (Table 3).

Table 3. Summary of analysis of variance and mean values for boll weight of upland cotton, under fertigation with reuse water in different percentages and phosphate fertilization, in two cultivation cycles

\begin{tabular}{|c|c|c|c|}
\hline \multirow{3}{*}{ SV } & \multirow{3}{*}{ DF } & \multicolumn{2}{|c|}{$\mathrm{F}$ test $\mathrm{Pr}>\mathrm{Fc}^{1}$} \\
\hline & & \multicolumn{2}{|c|}{ Cultivation cycle } \\
\hline & & 2016 & 2017 \\
\hline Block & 5 & $0.43^{\text {ns }}$ & $0.80^{\mathrm{ns}}$ \\
\hline Fertigation $(\mathrm{Fg})$ & 2 & $0.00^{* *}$ & $0.00^{* *}$ \\
\hline Fertilization (Ft) & 1 & $0.53^{\text {ns }}$ & $0.06^{\mathrm{ns}}$ \\
\hline $\mathrm{Fg} \times \mathrm{Ft}$ & 2 & $0.70^{\mathrm{ns}}$ & $0.87^{\mathrm{ns}}$ \\
\hline Error & 25 & & \\
\hline CV $(\%)$ & & 4.75 & 4.62 \\
\hline Fertigation $^{2}$ & & \multicolumn{2}{|c|}{ Boll weight $(\mathrm{q})^{3}$} \\
\hline $\mathrm{T}_{1}-100 \% \mathrm{SW}$ & & $4.41 \mathrm{~b}$ & $4.24 b$ \\
\hline $\mathrm{T}_{2}-50 \% \mathrm{SW}+50 \% \mathrm{RW}$ & & $5.32 \mathrm{a}$ & $5.36 \mathrm{a}$ \\
\hline $\mathrm{T}_{3}-100 \% \mathrm{RW}$ & & $5.41 \mathrm{~b}$ & $5.55 \mathrm{a}$ \\
\hline LSD & & 0.24 & 0.23 \\
\hline
\end{tabular}

SV - Sources of variation; DF - Degrees of freedom; CV - Coefficient of variation; LSD - Least significant difference; ${ }^{1}$ Values of Pr - Fc equal to or lower than 0.05 and greater than 0.01 indicate significant difference at $\mathrm{p} \leq 0.05\left(^{*}\right)$, values equal to or lower than 0.01 indicate significance at $\mathrm{p} \leq 0.01\left(^{* *}\right)$ and values greater than 0.05 indicate no significance. ${ }^{2} \mathrm{SW}$ - supply water and RW - reuse water. ${ }^{3}$ Equal letters do not differ by Tukey test at $\mathrm{p} \leq 0.05$
Fertigation with reuse water caused significant increments in boll weight in both cultivation cycles, which corresponded to 20.6 and $22.7 \%$ in the first cycle and to 26.4 and $30.9 \%$ in the second cycle in the treatments $\mathrm{T}_{2}$ and $\mathrm{T}_{3}$, respectively, compared to the means of 4.41 and $4.24 \mathrm{~g}$ recorded in $\mathrm{T}_{1}$ in the respective cycles (Table 3 ).

Reuse water has significantly higher concentrations of $\mathrm{N}$, $\mathrm{P}$ and $\mathrm{K}$ compared to local supply water (Table 2). Therefore, the higher boll weight may be related to the supply of these nutrients, which are essential for the development of cotton crop. The nutritional potential of wastewater was also verified by Silva et al. (2013), who observed increments of $16 \%$ in boll weight and $269.36 \%$ in seed cotton production when cotton plants were fertigated with treated wastewater, compared to those irrigated with supply water. Santos et al. (2016) found seed cotton production (3098.51 kg ha-1) in plants irrigated with reuse water similar to that of plants cultivated under topdressing mineral fertilization $\left(2548.57 \mathrm{~kg} \mathrm{ha}^{-1}\right)$.

There was no significant effect on the increase in boll weight when comparing only the treatments of fertigation with reuse water $\left(\mathrm{T}_{2}\right.$ and $\left.\mathrm{T}_{3}\right)$ (Table 3 ). This fact confirms that fertigation with $50 \%$ RW leads to a yield close to the maximum of the crop (100\% of the fertigation with RW), which represented applications of 354.8 and $379.5 \mathrm{~mm}$ during the first and second development cycles, respectively. These water depths using $100 \%$ RW supplied 148.7 and $168.6 \mathrm{~kg} \mathrm{ha}^{-1}$ of $\mathrm{N}$ in the first and second cycles, respectively. These values exceed the requirement of the crop, which is $131 \mathrm{~kg} \mathrm{ha}^{-1}$ of $\mathrm{N}$ according to Teixeira et al. (2008), for high yield.

Fertigation with $100 \%$ of reuse water also supplied $26.12 \mathrm{~kg} \mathrm{ha}^{-1}$ of $\mathrm{P}$ in the first cycle and $29.7 \mathrm{~kg} \mathrm{ha}^{-1}$ in the second cycle. These values are below the $52 \mathrm{~kg} \mathrm{ha}^{-1}$ found by Batista et al. (2010), for the maximum yield of the crop. In turn, the supply of $\mathrm{K}$ was equal to 91.42 and $103.8 \mathrm{~kg} \mathrm{ha}^{-1}$ in the first and second cycles, respectively, which are slightly below the $121 \mathrm{~kg} \mathrm{ha}^{-1}$ recommended by Bernardi et al. (2009), for maximum cotton yield. These results imply that fertigation with $100 \%$ ETc with reuse water $(100 \%)$ promotes a good supply of $\mathrm{N}, \mathrm{P}$ and $\mathrm{K}$ for cotton crop.

The average results obtained for upland cotton boll weight were $4.33 \mathrm{~g}$ for $\mathrm{T}_{1}, 5.34 \mathrm{~g}$ for $\mathrm{T}_{2}$ and $5.48 \mathrm{~g}$ for $\mathrm{T}_{3}$, in the two cultivation cycles (Table 4 ), which are within the range observed by Alves et al. (2019) evaluating the ten varieties of cotton in the Agreste region of Pernambuco, Brazil, with boll weight ranging from 3.94 to $8.78 \mathrm{~g}$. Boll weight values in the treatments with reuse water were higher than those observed by Nascimento et al. (2018), evaluating the production of cotton cultivar BRS Topázio as a function of different types of domestic reuse wastewater, with variations from 4.55 to 5.10 g per boll. Ferreira et al. (2018), working with upland cotton BRS Araripe cultivated under different sources of organic fertilization (cattle manure, carbonized rice straw), observed boll weights ranging from 5.5 to $7.8 \mathrm{~g}$, results that are higher than the ones obtained in the present study.

There was a significant individual effect of fertigation with reuse water on $\mathrm{K}, \mathrm{Ca}, \mathrm{Mg}, \mathrm{Fe}, \mathrm{Mn}$ and $\mathrm{Zn}$ contents and of phosphate fertilization on $\mathrm{P}$ content in the first cultivation cycle (2016). In the second cycle (2017), the interaction between 
fertigation with reuse water and phosphate fertilization had a significant effect on $\mathrm{P}$ content whereas fertigation with reuse water had a significant individual effect on $\mathrm{N}, \mathrm{Ca}, \mathrm{Mg}, \mathrm{Cu}, \mathrm{Fe}$, Mn and $\mathrm{Zn}$ contents (Table 4).

The average $\mathrm{N}$ concentrations in the first cycle were below the levels considered adequate, which are between 35.0 and 40.0 $\mathrm{g} \mathrm{kg}^{-1}$ (Malavolta et al., 1997), although higher in treatments under fertigation with reuse water. In the second cycle, the average $\mathrm{N}$ concentrations were still below the optimum range in treatment $\mathrm{T}_{1}(100 \% \mathrm{SW})$, showing an even greater deficiency in the following cycle, which resulted from soil depletion, while treatments under fertigation with reuse water in the second cycle had levels within the range considered adequate (Malavolta et al., 1997). This is due to the $\mathrm{N}$ supply provided by fertigation with reuse water (Table 2 ). The increase in leaf $\mathrm{N}$ contents of cotton plants as a function of reuse water application at 50 days after emergence (DAE) was also observed by Silva et al. (2013).

Plants that received $\mathrm{P}$ at pre-planting in the first cycle showed $25 \%$ higher nutrient contents than those in treatments without fertilization (Table 4). However, the leaf concentrations of $\mathrm{P}$, in the first and second cycles, are higher than the adequate levels in all treatments, which are between 2.0 and $2.5 \mathrm{~g} \mathrm{~kg}^{-1}$ (Malavolta et al., 1997) (Table 4).
In the second cycle, there was interaction between the factors, and plants under irrigation with supply water and phosphate fertilization had the highest leaf $\mathrm{P}$ concentrations, with no difference between the other treatments (Figure 1).

The average $\mathrm{K}$ contents in the first cycle were higher than the adequate levels, which are between 14.0 and $16.0 \mathrm{~g} \mathrm{~kg}^{-1}$ (Malavolta et al., 1997), with values of $15.3,17.8$ and $22.6 \mathrm{~g}$ $\mathrm{kg}^{-1}$ in leaves of cotton fertigated with $\mathrm{T}_{1}(100 \% \mathrm{SW}), \mathrm{T}_{2}(50 \%$ $\mathrm{SW}+50 \% \mathrm{RW})$ and $\mathrm{T}_{3}(100 \% \mathrm{RW})$, respectively (Table 4$)$. The higher $\mathrm{K}$ contents in the first cycle are due to the high initial concentrations of $\mathrm{K}$ present in the soil, before the crop was planted (Table 1), leading to luxury consumption. However, in the second cycle, the K concentrations observed (14.5 to 15.7 $\mathrm{g} \mathrm{kg}^{-1}$ ) are within the optimum range for the crop (Table 4).

The average $\mathrm{Ca}$ concentrations are below the adequate levels, which are between 30.0 and $40.0 \mathrm{~g} \mathrm{~kg}^{-1}$ (Malavolta et al., 1997) in both cultivation cycles. The highest Ca contents were observed in plants irrigated with supply water (Table 4). This behavior of $\mathrm{Ca}$ occurs because the irrigation water came from a tubular well and the soil is of calcareous origin, and both sources contain considerable quantities of $\mathrm{Ca}$ (Tables 1 and 2).

The Mg contents showed variable behavior, and plants in $\mathrm{T}_{1}$ and $\mathrm{T}_{2}$ treatments had nutrient concentrations below adequate (4.0-5.0 $\left.\mathrm{g} \mathrm{kg}^{-1}\right)$, while those in $\mathrm{T}_{3}$ obtained adequate values in

Table 4. Summary of the analysis of variance and mean values for the concentrations of macronutrients and micronutrients in the diagnostic leaf of upland cotton as a function of fertigation with reuse water and phosphate fertilization, in two cultivation cycles

\begin{tabular}{|c|c|c|c|c|c|c|c|c|c|c|}
\hline \multirow{2}{*}{ SV } & \multirow{2}{*}{ DF } & \multicolumn{9}{|c|}{$\mathrm{F}$ test $\mathrm{Pr}>\mathrm{Fc}^{1}$} \\
\hline & & $\mathbf{N}$ & $\mathbf{P}$ & K & $\mathrm{Ca}$ & $\mathrm{Mg}$ & Cu & $\mathrm{Fe}$ & Mn & $\mathrm{Zn}$ \\
\hline & & \multicolumn{9}{|c|}{2016 cycle } \\
\hline Block & 5 & $0.98^{\text {ns }}$ & $0.54^{\mathrm{ns}}$ & $0.30^{\text {ns }}$ & $0.01 *$ & $0.20^{\mathrm{ns}}$ & $0.60^{\text {ns }}$ & $0.38^{\text {ns }}$ & $0.19^{\text {ns }}$ & $0.12^{\mathrm{ns}}$ \\
\hline Fertigation (Fg) & 2 & $0.16^{\mathrm{ns}}$ & $0.12^{\mathrm{ns}}$ & $0.00 * *$ & $0.00 * *$ & $0.00 * *$ & $0.41^{\mathrm{ns}}$ & $0.02^{*}$ & $0.00 * \star$ & $0.01^{*}$ \\
\hline Fertilization (Ft) & 1 & $0.58^{\text {ns }}$ & $0.04^{*}$ & $0.32^{\mathrm{ns}}$ & $0.85^{\text {ns }}$ & $0.35^{\text {ns }}$ & $0.07^{\mathrm{ns}}$ & $0.66^{\text {ns }}$ & $0.95^{\mathrm{ns}}$ & $0.81^{\mathrm{ns}}$ \\
\hline $\mathrm{Fg} \times \mathrm{Ft}$ & 2 & $0.38^{\text {ns }}$ & $0.96^{\text {ns }}$ & $0.36^{\text {ns }}$ & $0.80^{\text {ns }}$ & $0.63^{\text {ns }}$ & $0.95^{\text {ns }}$ & $0.30^{\text {ns }}$ & $0.90^{\text {ns }}$ & $0.15^{\mathrm{ns}}$ \\
\hline Error & 25 & & & & & & & & & \\
\hline CV (\%) & & 14.33 & 30.84 & 17.92 & 27.84 & 32.50 & 26.38 & 20.12 & 28.96 & 44.02 \\
\hline Fertigation ${ }^{2}$ & & \multicolumn{5}{|c|}{$\left(\mathrm{g} \mathrm{kg}^{-1}\right)$} & \multicolumn{4}{|c|}{$\left(\mathrm{mg} \mathrm{kg}^{-1}\right)$} \\
\hline $\mathrm{T}_{1}-100 \% \mathrm{SW}$ & & $29.47 \mathrm{a}$ & $5.6 \mathrm{a}$ & $15.3 \mathrm{~b}$ & $24.16 \mathrm{a}$ & $2.71 \mathrm{~b}$ & $1.60 \mathrm{a}$ & $31.66 \mathrm{~b}$ & $75.91 b$ & $18.05 \mathrm{~b}$ \\
\hline $\mathrm{T}_{2}-50 \% \mathrm{SW}+50 \% \mathrm{RW}$ & & $32.74 \mathrm{a}$ & $4.3 \mathrm{a}$ & $17.8 \mathrm{~b}$ & $17.76 b$ & $1.93 \mathrm{~b}$ & $1.47 \mathrm{a}$ & $40.50 \mathrm{a}$ & $108.50 \mathrm{~b}$ & $17.00 \mathrm{~b}$ \\
\hline $\mathrm{T}_{3}-100 \% \mathrm{RW}$ & & $32.50 \mathrm{a}$ & $4.8 \mathrm{a}$ & $22.6 \mathrm{a}$ & $14.09 b$ & $6.88 \mathrm{a}$ & $1.38 \mathrm{a}$ & $36.25 a b$ & $447.66 \mathrm{a}$ & $27.58 \mathrm{a}$ \\
\hline LSD & & 4.60 & 1.50 & 3.40 & 5.28 & 1.27 & 0.39 & 7.39 & 62.07 & 9.35 \\
\hline \multicolumn{11}{|l|}{ Phosphate fertilization? } \\
\hline With $P$ & & $31.15 \mathrm{a}$ & $5.5 \mathrm{a}$ & $18.0 \mathrm{a}$ & $18.83 \mathrm{a}$ & $4.03 \mathrm{a}$ & $1.60 \mathrm{a}$ & $35.61 \mathrm{a}$ & $211.33 \mathrm{a}$ & $20.51 \mathrm{a}$ \\
\hline Without P & & $31.99 \mathrm{a}$ & $4.4 \mathrm{~b}$ & $19.1 \mathrm{a}$ & $18.51 \mathrm{a}$ & $3.64 \mathrm{a}$ & $1.36 \mathrm{a}$ & $36.66 \mathrm{a}$ & $210.05 a$ & $21.25 \mathrm{a}$ \\
\hline LSD & & 3.10 & 1.00 & 2.20 & 3.56 & 0.85 & 0.26 & 4.99 & 41.88 & 6.31 \\
\hline & & \multicolumn{9}{|c|}{2017 cycle } \\
\hline Block & 5 & $0.11^{\mathrm{ns}}$ & $0.78^{\text {ns }}$ & $0.29^{\text {ns }}$ & $0.10^{\text {ns }}$ & $0.26^{\text {ns }}$ & $0.58^{\mathrm{ns}}$ & $0.80^{\text {ns }}$ & $0.04^{*}$ & $0.29^{\mathrm{ns}}$ \\
\hline Fertigation (Fg) & 2 & $0.00 *$ & $0.00 *$ & $0.11^{\mathrm{ns}}$ & $0.00 *$ & $0.00 *$ & $0.02^{\star}$ & $0.03 *$ & $0.00 *$ & $0.00 *$ \\
\hline Fertilization (Ft) & 1 & $0.23^{\text {ns }}$ & $0.01 *$ & $0.93^{\text {ns }}$ & $0.78^{\text {ns }}$ & $0.65^{\text {ns }}$ & $0.08^{\text {ns }}$ & $0.82^{\text {ns }}$ & $0.90^{\text {ns }}$ & $0.75^{\mathrm{ns}}$ \\
\hline $\mathrm{Fg} \times \mathrm{Ft}$ & 2 & $0.50^{\text {ns }}$ & $0.00 *$ & $0.86^{\text {ns }}$ & $0.82^{\text {ns }}$ & $0.35^{\text {ns }}$ & $0.90^{\text {ns }}$ & $0.96^{\text {ns }}$ & $0.85^{\mathrm{ns}}$ & $0.91^{\text {ns }}$ \\
\hline Error & 25 & & & & & & & & & \\
\hline CV (\%) & & 6.53 & 21.28 & 10.05 & 25.55 & 16.16 & 9.65 & 11.28 & 13.08 & 8.29 \\
\hline \multicolumn{11}{|l|}{ Fertigation ${ }^{2}$} \\
\hline $\mathrm{T}_{1}-100 \% \mathrm{SW}$ & & $28.32 b$ & $4.7 \mathrm{a}$ & $14.5 \mathrm{a}$ & $27.74 \mathrm{a}$ & $2.24 \mathrm{~b}$ & $0.95 \mathrm{ab}$ & $44.66 \mathrm{ab}$ & $78.00 \mathrm{C}$ & $8.59 \mathrm{a}$ \\
\hline $\mathrm{T}_{2}-50 \% \mathrm{SW}+50 \% \mathrm{RW}$ & & $41.18 \mathrm{a}$ & $3.2 \mathrm{~b}$ & $14.6 \mathrm{a}$ & $14.31 \mathrm{~b}$ & $2.13 b$ & $1.00 \mathrm{a}$ & $48.41 \mathrm{a}$ & $98.50 \mathrm{~b}$ & $8.02 \mathrm{a}$ \\
\hline $\mathrm{T}_{3}-100 \% \mathrm{RW}$ & & $43.65 \mathrm{a}$ & $2.7 \mathrm{~b}$ & $15.7 \mathrm{a}$ & $13.5 \mathrm{~b}$ & $10.33 \mathrm{a}$ & $0.89 \mathrm{~b}$ & $42.66 \mathrm{~b}$ & $221.16 \mathrm{a}$ & $5.90 \mathrm{~b}$ \\
\hline LSD & & 2.5 & 0.7 & 1.5 & 4.81 & 0.8 & 0.09 & 5.19 & 17.63 & 0.63 \\
\hline \multicolumn{11}{|l|}{ Phosphate fertilization ${ }^{2}$} \\
\hline With $\mathrm{P}$ & & $37.22 \mathrm{a}$ & $3.9 \mathrm{a}$ & $14.9 \mathrm{a}$ & $18.73 \mathrm{a}$ & $4.96 \mathrm{a}$ & $0.96 \mathrm{a}$ & $45.44 \mathrm{a}$ & $132.22 \mathrm{a}$ & $7.47 \mathrm{a}$ \\
\hline Without P & & $38.21 \mathrm{a}$ & $3.2 \mathrm{~b}$ & $14.9 \mathrm{a}$ & $18.3 \mathrm{a}$ & $4.84 \mathrm{a}$ & $0.93 \mathrm{a}$ & $45.05 \mathrm{a}$ & $132.88 \mathrm{a}$ & $7.53 \mathrm{a}$ \\
\hline LSD & & 1.69 & 0.5 & 1.0 & 3.24 & 0.54 & 0.06 & 3.5 & 11.90 & 0.42 \\
\hline
\end{tabular}

SV - Sources of variation; DF - Degrees of freedom; CV - Coefficient of variation; LSD - Least significant difference; ${ }^{1}$ Values of Pr $>$ Fc equal to or lower than 0.05 indicate a significant difference at $\mathrm{p} \leq 0.05\left({ }^{*}\right)$, values equal to or lower than 0.01 indicate significance at $\mathrm{p} \leq 0.01\left({ }^{* *}\right) .{ }^{2} \mathrm{SW}$ - supply water and RW - reuse water; Equal letters do not differ by Tukey test at $\mathrm{p} \leq 0.05$ 


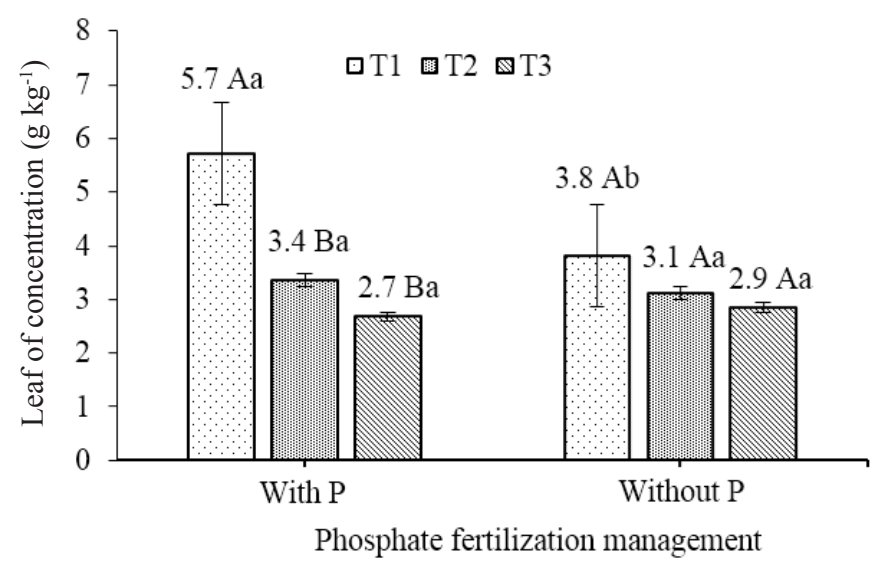

Means followed by the same uppercase letter (A, B) for treatments within management, and lowercase letter $(\mathrm{a}, \mathrm{b})$ for management within treatments, do not differ at $\mathrm{p} \leq 0.05$ by Tukey Test

Figure 1. Leaf phosphorus $(\mathrm{P})$ content in cotton plants fertigated with supply water $\left(\mathrm{T}_{1}-100 \% \mathrm{SW}\right)$ and reuse water $\left(\mathrm{T}_{2}-50 \% \mathrm{SW}\right.$ $+50 \% \mathrm{RW}$; and $\left.\mathrm{T}_{3}-100 \% \mathrm{RW}\right)$ and under phosphate fertilization in the second cycle of cultivation (2017)

the two cultivation cycles (Malavolta et al., 1997). In the second cycle, there was a significant difference between fertigation treatments, and $\mathrm{T}_{3}$ led to higher contents compared to $\mathrm{T}_{1}$ and $\mathrm{T}_{2}$ (Table 4). This indicates that the types of fertigation with reuse water at $100 \%$ concentration adequately supplied $\mathrm{Mg}$ for the cotton crop to obtain high yield.

In the second cycle, $\mathrm{T}_{2}$ resulted in the highest $\mathrm{Cu}$ concentrations compared to the other treatments; however, the average $\mathrm{Cu}$ contents of cotton plants were considered below adequate $\left(30.0-40.0 \mathrm{mg} \mathrm{kg}^{-1}\right)$ in the two cultivation cycles, according to Malavolta et al. (1997). For Fe conte concentrations nts, plants in $\mathrm{T}_{2}$ also obtained higher concentrations of this micronutrient for the two cycles of cultivation; however, its contents were lower than the range considered adequate for cotton, which is between 60.0 and $80.0 \mathrm{mg} \mathrm{kg}^{-1}$ (Malavolta et al., 1997) (Table 4).

The average levels of $\mathrm{Mn}$ in cotton plants higher than the adequate levels (20.0-40.0 $\mathrm{mg} \mathrm{kg}^{-1}$ ) (Malavolta et al., 1997), in all treatments in the two cultivation cycles, with better performance of treatments under fertigation, mainly $\mathrm{T}_{3}$, due to the nutrient supply provided by reuse water (Tables 2 and 4).

$\mathrm{Zn}$ concentrations were above the adequate levels in the first cycle (10.0-15.0 $\mathrm{mg} \mathrm{kg}^{-1}$ ) (Malavolta et al., 1997) and lower than the adequate levels in the second cycle in all treatments. The highest values were observed in the absence of fertigation (Table 4). The data indicate that the luxury consumption of $\mathrm{Zn}$ in the first cycle limited its availability in the next cycle, and this effect was more noticeable in plants fertigated with reuse water, due to the greater development and production (Table 3).

In general, the $\mathrm{Mg}$ concentrations were adequately supplied, and there was luxury consumption of $\mathrm{P}, \mathrm{K}$ and $\mathrm{Mn}$ due to the supply of these nutrients by the soil and reuse water (Tables 1 and 2). $\mathrm{Ca}, \mathrm{Cu}, \mathrm{Fe}$ and $\mathrm{Zn}$ contents in cotton leaves were below the optimum range for the crop to obtain high yield (Malavolta et al., 1997). Therefore, under the present conditions of cultivation, in addition to fertigation with reuse water, complementary foliar fertilization with $\mathrm{Ca}, \mathrm{Cu}, \mathrm{Fe}$ and $\mathrm{Zn}$ at pre-flowering are recommended for the crop in order to maintain high yields in successive cycles.

\section{Conclusions}

1. Fertigation with wastewater at a concentration of $50 \%$ increased boll weight of upland cotton.

2. Fertigation with $100 \%$ reuse water proved to be feasible to meet the nutritional requirement of cotton, improving its nutritional status in the first two cultivation cycles.

3. Reuse water did not meet the total requirements of $\mathrm{Ca}, \mathrm{Cu}, \mathrm{Fe}$ and $\mathrm{Zn}$ of cotton, so complementary mineral supplementation with these nutrients is recommended for the crop to obtain high yield.

4. Cotton P requirement was fully met by the P present in the reuse water, which indicates that phosphate fertilization is dispensable when reuse water is used in fertigation.

\section{ACKnOWLedgements}

This work was supported by the Coordenação de Aperfeiçoamento de Pessoal de Nível Superior (CAPES) - Financing Code 001 and by the Conselho Nacional de Desenvolvimento Científico e Tecnológico (CNPq).

\section{Literature Cited}

Abdoulkader, B. A.; Mohamed, B.; Nabil, M.; Alaoui-Sossé, B.; Eric, C.; Aleya, L. Wastewater use in agriculture in Djibouti: Effectiveness of sand filtration treatments and impact of wastewater irrigation on growth and yield of Panicum maximum. Ecological Engineering, v.84, p.607-614, 2015. https://doi.org/10.1016/j. ecoleng.2015.09.065

Allen, R. G.; Pereira, L. S.; Raes, D.; Smith, M. Evapotraspiración del cultivo. Guías para la determinación de los requerimientos de água de los cultivos. Rome: FAO, 2006. 323p. Paper, 56.

Alves, F. A. L.; Cavalcante, F. S.; Oliveira Júnior, I. S.; Ferraz, I.; Silva, S. M. S. Competição de variedades de algodão herbáceo para cultivo no agreste pernambucano. Pesquisa Agropecuária Pernambucana, v.24, p.e1971242019, 2019. https://doi.org/10.12661/pap.2019.003

Aquino, L. A. de; Berger, P. G.; Neves, J. C. L.; Lima, T. C.; Aquino, R. F. B. A. de. Parcelamento de fósforo em algodoeiro irrigado. Pesquisa Agropecuária Tropical, v.42, p.1-8, 2012. https://doi. org/10.1590/S1983-40632012000100001

Barbosa, B.; Costa, J.; Fernando, A. L.; Papazoglou, E. G. Wastewater reuse for fiber crops cultivation as a strategy to mitigate desertification. Industrial Crops and Products, v.68, p.17-23, 2015. https://doi.org/10.1016/j.indcrop.2014.07.007

Batista, A. A.; Dutra, I.; Carmo, F. F. do; Izidio, N. S. de C.; Batista, R. O. Qualidade dos frutos de mamoeiro produzidos com esgoto doméstico tratado. Revista Ciência Agronômica, v.48, p.70-80, 2017.

Batista, C. H.; Aquino, L. A.; Silva, T. R.; Silva, H. R. F. Crescimento e produtividade da cultura do algodão em resposta a aplicação de fósforo e métodos de irrigação. Revista Brasileira de Agricultura Irrigada, v.4, p.197-206, 2010. https://doi.org/10.7127/rbai. $\mathrm{v} 4 \mathrm{n} 400035$

Bernardi, A. C. de C.; Oliveira Júnior, J. P. de; Leandro, W. M.; Mesquita, T. G. da S.; Freitas, P. L. de; Carvalho, M. da C. S. Doses e formas de aplicação da adubação potássica na rotação soja, milheto e algodão em sistema plantio direto. Pesquisa Agropecuária Tropical, v.39, p.158-167, 2009. 
Bonsch, M.; Poppa, A.; Biewald, A.; Rolinski, A.; Schmitz, S.; Weindl, I.; Stevanovi, M.; Högner, K.; Heinke, J.; Ostberg, S.; Dietrich, J. P.; Bodirsky, B.; Campena, H. L.; Humpenöder, F. Agricultural green and blue water consumption and its influence on the global water system. Global Environmental Change, v.30, p.113-132, 2015. https://doi.org/10.1016/j.gloenvcha.2014.10.015

Cary, L.; Surdyk, N.; Psarras, G.; Kasapakis, I.; Chartzoulakis, K.; Sandei, L.; Guerrot, C.; Pettenati, M.; Kloppman, W. Short-term assessment of dynamics of elements in wastewater irrigated Mediterranean soil and tomato fruits through sequencial dissolution and lead isotopic signatures. Agricultural Water Management, v.155, p.87-99, 2015. https://doi.org/10.1016/j. agwat.2015.03.016

Diniz, M. T. M.; Pereira, V. H. C. Climatologia do estado do Rio Grande do Norte, Brasil: sistemas atmosféricos atuantes e mapeamento de tipos de clima. Boletim Goiano de Geografia, v.35, p.488-506, 2015. https://doi.org/10.5216/bgg.v35i3.38839

Ferreira, D. F. Sisvar: A guide for its bootstrap procedures in multiple comparisons. Ciência e Agrotecnologia, v.38, p.109-112, 2014. https://doi.org/10.1590/S1413-70542014000200001

Ferreira, M. M.; Tartaglia, F. L.; Fulaneti, F. S.; Alencar, C. C.; Santos, E. M.; Alves, G. S. Crescimento e produtividade do algodoeiro herbáceo submetido à adubação orgânica. Revista Brasileira de Agropecuária Sustentável, v.8, p.52-61, 2018. https://doi. org/10.21206/rbas.v8i2.475

Hao, F.; Li, J.; Wang, Z.; Li, Y. Effect of ions on clogging and biofilm formation in drip emitters applying secondary sewage effluent. Irrigation and Drainage, v.66, p.687-698, 2017. https://doi. org/10.1002/ird.2141

Lima, R. F. de; Araújo, W. P.; Pereira, J. R.; Cordão, M. A.; Ferreira, F. N.; Zonta, J. H. Fibras de algodoeiro herbáceo sob déficit hídrico. Revista Verde de Agroecologia e Desenvolvimento Sustentável, v.13, p.427-436, 2018. https://doi.org/10.18378/rvads.v13i4.5940

Malavolta, E.; Vitti, G. C.; Oliveira, S. A. de. Avaliação do estado nutricional das plantas: Princípios e aplicações. 2.ed. Piracicaba: Potafos, 1997. 319p.

Mekki, A.; Fki, F.; Kchaou, M.; Sayadi, S. Short-term effects of gray wastewater on a Meditterranean sandy soil. Clean - Soil Air Water, v.43, p.621-786, 2014. https://doi.org/10.1002/clen.201400049
Nascimento, J. dos S.; Souza, T. A.; Fideles Filho, J.; Beirigo, R. M. Avaliação do crescimento, desenvolvimento e produção do algodão irrigado com água de esgotos sanitários tratados. Agropecuária Científica no Semiárido, v.14, p.331-338, 2018. https://doi.org/10.30969/acsa.v14i4.1052

PROSAB - Programa de Pesquisas em Saneamento Básico. Tratamento de esgotos sanitários por processo anaeróbio e disposição controlada no solo. 1 ed. Rio de Janeiro: ABES,1999, p.139-154.

Rost, S.; Gerten, D.; Bondeau, A.; Lucht, W.; Rohwer, J.; Schaphoff, S. Agricultural green and blue water consumption and its influence on the global water system. Water Resources Research, v.44, p.117, 2008. https://doi.org/10.1029/2007WR006331

Ribeiro, A. C.; Guimarães, P. T. G.; Alvarez V., V. H. Recomendações para o uso de corretivos e fertilizantes em Minas Gerais: $5^{\mathrm{a}}$ aproximação. Viçosa: Editora UFV, 1999. 259p.

Ribeiro, M. C. de F.; Rocha, F. A.; Santos, A. C. dos; Silva, J. O. da; Peixoto, M. de F. S. P.; Paz, V. P. da S. Crescimento e produtividade da mamoneira irrigada com diferentes diluições de esgoto doméstico tratado. Revista Brasileira de Engenharia Agrícola e Ambiental, v.16, p.639-646, 2012. https://doi.org/10.1590/S141543662012000600008

Santos, S. R.; Soares, A. A.; Kondo, M. K.; Araujo, E. D.; Cecon, P. R. Crescimento e produção do algodoeiro fertirrigado com água residuária sanitária no semiárido de Minas Gerais. Irriga, v.21, p.40-54, 2016. https://doi.org/10.15809/irriga.2016v21n1p40-57

Silva, F. C. da. Manual de análises químicas de solos, plantas e fertilizantes. Brasília: Informação Tecnológica, 2009. 370p.

Silva, L. V. B. D.; Lima, V. L. A. de; Silva, V. N. B.; Sofiatti, V.; Pereira, T. L. P. Torta de mamona residual e irrigação com efluente sobre crescimento e produção de algodoeiro herbáceo. Revista Brasileira de Engenharia Agrícola e Ambiental, v.17, p.1264-70, 2013. https://doi.org/10.1590/S1415-43662013001200003

Teixeira, I. R.; Kikuti, H.; Borém, A. Crescimento e produtividade de algodoeiro submetido a cloreto de mepiquat e doses de nitrogênio. Bragantia, v.67, p.891-897, 2008. https://doi.org/10.1590/S000687052008000400011

USDA - United States Department of Agriculture. Cotton world supply, use and trade. Available on: <https://www.fas.usda.gov/ data/ cotton-world-markets-and-trade $>$. Accessed on: Mar. 2018. 